\title{
DYNAMICS OF AUSTRIAN FOREIGN DIRECT INVESTMENT AND THEIR INFLUENCE ON THE NATIONAL ECONOMY
}

\author{
Iryna Lomachynska', Serhii Yakubovskiy², Ivan Plets ${ }^{3}$
}

\begin{abstract}
The purpose of the paper is to analyse the dynamics of Austrian foreign direct investments (FDI) and its role in the development of the national economy. The subject of research is the main components of Austrian foreign direct investments 2005-2017 and their impact on the national economic development. Methodology. Methods of comparative and statistical analysis were used to study the dynamics, structure, and economic impact of Austria's FDI. Special attention was given to the dynamics of FDI inflows and outflows, accumulated investments, cross-border mergers and acquisitions, "Greenfield Investments", the impact of FDI on the balance of payments and international investment position of Austria. The method of mathematical modelling in economics, in particular, regression analysis, based on annual data for the period from 2005 to 2015, was applied to assess the relationship between the main components of foreign direct investments and the indicator of the country's economic growth the gross domestic product (GDP) per capita. The following indicators were selected as independent variables: FDI liabilities, assets of FDI funds, as well as the balance of primary incomes. The dependent variable was the GDP per capita. It should be noted that such indicators as FDI assets and liabilities of FDI funds were not represented in the final model because of the high correlation between independent variables, and the relationship between GDP per capita and net foreign assets was insignificant. The assets of foreign direct investment funds have the greatest impact on the economy of the country, and the relationship between these indicators is direct. A slightly weaker relationship is observed between the balance of primary incomes and GDP per capita. The relationship between them is also direct. Liabilities of FDI have the least impact on the dependent variable in comparison with the other two. Findings. The growth of foreign direct investments of Austria, as a result of liberalization of the world and European economy, as a whole has a positive impact on its GDP. Thus, activities that are aimed at stimulating investments are fully justified and understandable. The paper determines important factors of Austria's investment activity and attractiveness, as well as the main factors that influence the dynamics of FDI. The most important among them are: the level of education, the internal coefficient of investment, political stability, the terms of trade, the state of the financial sector. The results of the analysis show that Austria has a high level of business activity; the government conducts activities to stimulate investment in R\&D and in high-tech enterprises, to create new jobs, to protect the environment etc. The results of the study allow forecasting a gradual improvement in the balance of the country's primary incomes, which will contribute to the further growth of the current account surplus and will strengthen the positive influence of Austria on the development of the European and global financial systems. Practical implications. The results of the study will help to increase: the effectiveness of the investment policy of Austria to stimulate the country's economic growth; the international competitiveness of national companies on European and world markets; the level of stability of Austria's financial system to external shocks.
\end{abstract}

Key words: foreign direct investments (FDI), components of FDI, investment policy, balance of payments, development of national economy, Austria.

JEL Classification: E22, E27, F21, G18

\footnotetext{
Corresponding author:

${ }^{1}$ Odessa I.I. Mechnikov National University, Ukraine.

E-mail: i.lomachynska@onu.edu.ua

ORCID: https://orcid.org/0000-0002-6112-6884

${ }^{2}$ Odessa I .I. Mechnikov National University, Ukraine.

E-mail: syakubovskiy@onu.edu.ua

ORCID: https://orcid.org/0000-0002-1193-0241

${ }^{3}$ Vasyl Stefanyk Precarpathian National University, Ukraine.

E-mail: ivanplets86@ukr.net

ORCID: https://orcid.org/0000-0002-9649-6770
} 


\section{Introduction}

Austria is a highly developed industrial country. Its geopolitical position between Western Europe (industrialized countries) and burgeoning markets of Central, Eastern, and South East Europe (CESEE) has provided a high degree of economic, social, political integration with EU countries and other countries CESEE, which are not EU members. Due to the external market access in Central and Eastern Europe, the Enlargement of the EU in 2004 and 2007 has consolidated Austria's investment attractiveness. However, the Enlargement of the EU has also strengthened investment positions of Austria's competitors. As a result, nowadays, Budapest, Prague, and Bratislava compete with Vienna for foreign investors.

Nowadays, Austria has created special favourable conditions to attract foreign investors. The priority sectors for investment in Austria are high-tech and innovative industries. There are four major types of incentives for investment projects of companies registered in Austria: regional incentives, incentives for small and medium-sized enterprises, technology incentives, and environmental incentives. The government of the country provides assistance as subsidies to entrepreneurs, who operate investment projects targeted at supporting the creation of new jobs. The most common way to support foreign investment is to ensure the bank's guarantee for the preferential loan, provided for the implementation of investment projects. In case of implementing high risky or very large investment projects, conditions for participation in the distribution of a company's profit or additional non-risky rewards can be discussed.

Along with the supportive programs, a very important role for Austria's investment attractiveness play political stability and administrative transparency, rule of law, business environment, tax legislation, the protection of investors' rights, the stability of legislation and etc. Bilateral agreements, mainly with less-developed countries, have also a great influence on investments attraction in Austria (U.S. State Department, 2015).

Austrian Business Agency is a special structure for enterprises and investments attraction, which organizes contacts with potential investors and informs the business environment about Austria as a business platform. In general, since the foundation of the Agency in 1982, nearly 49.803 new jobs have been created and investments in the amount of almost $€ 7.25$ bn have been attracted (Austrian Business Agency, 2018).

In addition to this Agency, Austrian Economic Chambers (WKO), whose membership is compulsory for all Austrian companies, also helps Austrian companies in investing abroad. There is a government structure "Austrian Business Agency", as well as similar departments in each of the nine federal constituencies (counties) which provide an informative business support and offer different stimulating measures.
Meanwhile, foreign investors should take into account that Austria saves the essential features of the national economic model, established after the Second World War. For many years, the state played a major role in the country's economy. However, the state's role has significantly reduced as a result of structural adjustment policies and the large-scale privatization of the state holding company Österreichische Industrieholding (ÖIAG).

\section{Literature review}

Foreign direct investments play an important role in the development of national economies. Therefore, different aspects of FDI movement are investigated by both academics and international and national specialized institutions (IMF, UNCTAD, ECB, EBA, OECD, etc.).

Most of the modern applied and theoretical researches of the FDI movement are dedicated to developing countries. However, the proper attention is not paid to the analysis of the dynamics and structure of FDI in developed countries, including Austria. Authors focus their attention on the impact of FDI on employment, remuneration in the context of globalization (Onaran Ozlem, 2008), European economic integration (Beer et al., 2017) and disintegration processes (Sydorova, Yakubovskiy, 2017), role of FDI in Austria's innovation potential (Lomachynska, Podgorna, 2018), assess the impact of FDI from Austria on the development of the economies of the recipient countries (Petrakos et al., 2000; Kurtovic et al., 2016; Yakubovskiy et al., 2018), analyse the impact of the global financial crisis on the dynamics of GDP and FDI (Simionescu, 2016). Based on these studies, it can be summarized that the growth of Austria's FDI as a result of the liberalization of the world and the European economy had a positive impact on its GDP; had a positive influence on the development of the service sector, but did not have a significant impact on the export-oriented trades of the real sector; had a negative impact on wages and employment in Austria; contributed to the growth of transitive economies and their effectiveness. The global financial crisis, the decline in GDP growth and FDI in the CESEE countries negatively affected the investment activity and profitability of Austria.

At the same time, the changes in the dynamics of the inflow and outflow of Austrian FDI in modern conditions, as well as their factors, are insufficiently covered.

The paper's aim is to investigate the dynamics of the main components of Austria's FDI in 2005-2015.

\section{Dynamics of Austria's FDI and their main components}

The data of Austria's volume of foreign direct investment show a declining tendency for the last years. Figure 1 demonstrates the dynamics of inward and 


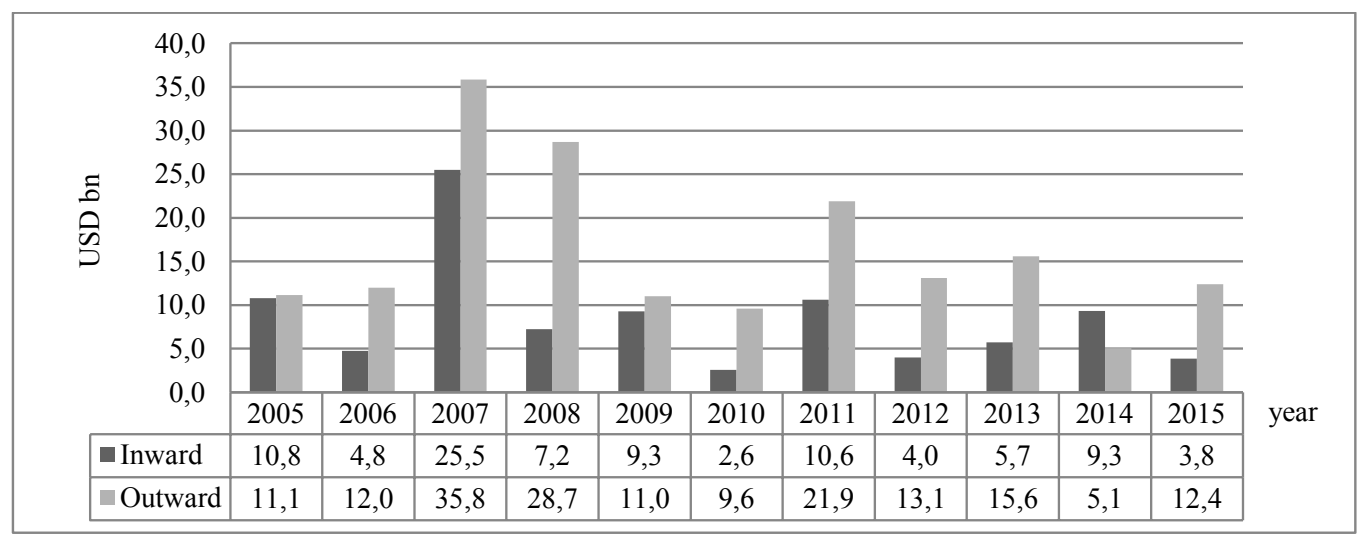

Figure 1. FDI flows of Austria

Source: compiled according to data (IMF, 2017)

outward of FDI in 2005-2015. During the pre-crisis period 2005-2007 inward of FDI increases and reaches $\$ 13.7$ bn in 2007, while the outward reaches $\$ 19.7$ bn. In the post-crisis period, FDI flows are rapidly declining and the minimal values are seen in 2010: the inward of FDI is $\$ 2.6 \mathrm{bn}$, the outward is $\$ 9.6 \mathrm{bn}$.

In spite of investment attractiveness, the dynamics of FDI in general shows that Austria is more a donor, rather than a recipient of foreign direct capital. Sharp changes in the dynamic of FDI can be observed only in 2014 when its outward has decreased by about three times, while the inward has gone up by more than 1,5 times. These changes can be explained by Austria's victory of "Eurovision" Song Contest in 2014. In terms of this contest, Austria as a winner held up this event in Vienna in 2015. The organization of such a type of event requires a large-scale preparation of the accompanying infrastructure, as well as a large capital investment on the eve (in 2014). In 2015, Austria's flows of FID have returned to its usual ratio, when the inflow is less than the outflow. Nevertheless, the inflow of FDI reduced to $\$ 3.8$ bn, outflow increased by $\$ 12.4 \mathrm{bn}$. Comparing with 2013 , both indicators have declined by nearly $\$ 2$ bn. This situation can be explained by European migration crisis at the beginning of 2015, which arose as a result of the rapid increase in the flow of refugees and illegal migrants to the European Union from North Africa and the Middle East. Political and economic instability in Ukraine, low growth prospects in the countries of SouthEast Asia had also a negative impact on the dynamics of Austrian FDI in 2013-2014.

Considering the changes of the FDI stocks of Austria (Fig. 2), first of all, it should be noted that despite of their small volume compared to developed countries of Western Europe, such as Germany and Great Britain, their role in Austria's economic and their ratio to country's GDP are no less important.

For the period from 1995 to 2015, the inward FDI stocks of Austria raised up by nearly 9 times (from $\$ 19$ bn to $\$ 164$ bn), while Austria's foreign investments stocks in other countries almost by 20 times (from $\$ 114$ bn to $\$ 208.3$ bn). This also confirms that Austria is gradually strengthening the position of the investor country.

There is also the increase in the share of the FDI stocks of Austria in GDP. If in 1995 the volume of FDI stocks in Austria in its GDP was 85\%, then from 2012 it exceeded by $40 \%$ and Austria's FDI stocks in other countries was $5 \%$ and 50\% accordingly. This allows to state that the modern development of the Austrian economy largely depends on the movement of foreign direct investment.

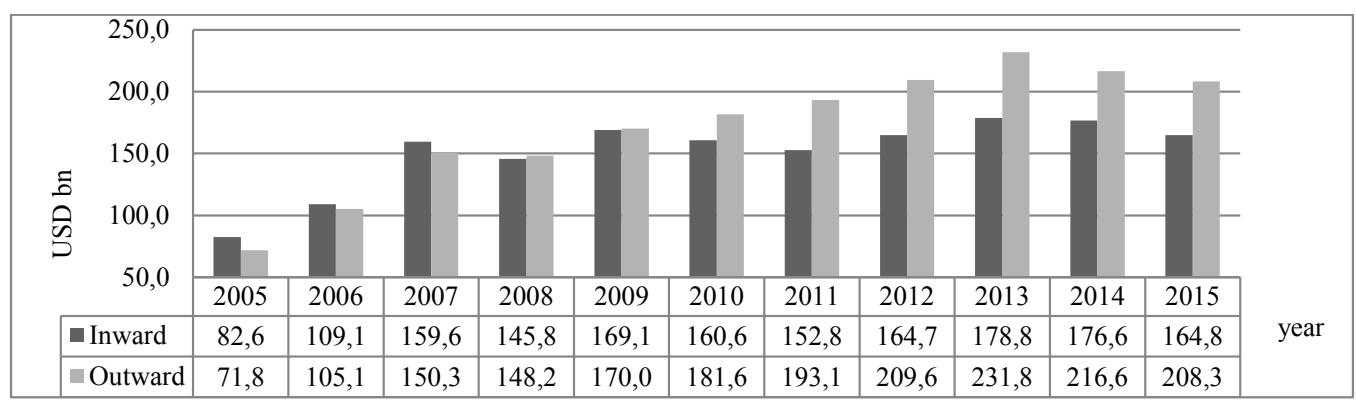

Figure 2. FDI stocks of Austria

Source: compiled according to data (IMF, 2017) 
Due to the territorial proximity, the absence of language, German companies are the leading investors of Austria's economy. As a result of the deepening of European integration in the last fifteen years, a significant share of investment is provided by the EU countries, primarily by Germany. Although, if earlier Germany accounted for more than $40 \%$ of FDI in Austria, nowadays the share of German investors does not reach even $25 \%$. The Netherlands, Italy, Luxembourg, and Russia are also the leaders of investing in Austria.

The dynamics of cross-border mergers and acquisitions of companies (M\&A) in Austria from 2005 to 2007 shows that M\&A transactions have been conducted in the amount of $\$ 3.9 \mathrm{bn}$, which is 11 times less than in Germany and 39 times that in the UK. There is a sharp increase in this indicator in 2014: the volume of the sales of Austrian companies in M\&A amounted to $\$ 3.07 \mathrm{bn}$, which corresponds to the trends of 2005-2007. In 2015, the volume of the sales of Austrian companies in M\&A fell by 3, 5 times and reached only $\$ 849 \mathrm{~m}$. In the years of 2005-2015, the volume of the purchasing of Austrian companies in M\&A is slightly higher than the amount of sales. This indicates the high activity of Austrian multinational companies. For three years from 2005 to 2007, the total value of transactions in M\&A amounted to $\$ 5.6$ bn. In 2013, this indicator has increased significantly - up to $\$ 10.7 \mathrm{bn}$. This also confirms that, unlike many other participants in the euro area, Austria quickly and successfully coped with the consequences of the global financial and economic crisis of 2008. However, in 2014 the amount of purchase transactions for mergers and acquisitions of companies decreased to $\$ 345 \mathrm{~m}$. Despite this sharp decline, the indicator began to recover in the next year and till the end of 2015, there were merger and acquisition transactions of companies amounting to $\$ 4.8 \mathrm{bn}$.

The dynamics of Greenfield Investments (investments in the "empty lot"), investments, which aimed at the creation of a new enterprise, demonstrate high activity in Austria during 2005-2015. From 2005 to 2007, $\$ 12.5$ bn was invested in the "empty lot" projects by Austrian investors and a high figure has been maintained for the past three years. In 2013, \$6.2 bn, $\$ 5.1$ bn in 2014, and $\$ 5.7$ bn in 2015 were invested in similar projects.

However, foreign investments in the "empty lot" projects in Austria for the whole analysed period is significantly less than in similar projects, which are invested by Austrian entrepreneurs. For the whole period of 2005-2007, only $\$ 2.8$ bn was invested in the "empty lot" projects. At the same time, for the last 3 years, this indicator has not changed significantly and remains at the level of $\$ 1.1-\$ 1.8 \mathrm{bn}$.

For the growth of the "Greenfield Investment" in Austria, the government of the country offers foreign companies additional investment incentives, primarily within the framework of regional and innovation policies. Growing competition of the Central and Eastern Europe compels the Austrian government to reduce the tax burden for enterprises (IMF, 2017). The corporate tax rate is $25 \%$, and by the estimation, it does not hinder to the development of foreign companies in Austria. In accordance with the Law on the Promotion of the Establishment of New Firms (NeugruendungsFoerderungsgesetz), new companies are exempted from paying taxes when buying a land plot, a court fee for the registration of a firm in the commercial register and the land registry, and other fees. In addition, there is a federal agency for Investment Promotion "Austrian Business Agency" (Bellak Ch., 2010; Austrian Business Agency, 2018), as well as similar agencies in each of the nine subjects of the federation (lands) that provide business information support and offer other incentive measures.

Analysing the balance of payments in Austria, first of all, the main attention should be paid to the current account of Austria (see Figure 3).

During the period of 2005-2015, the balance of the current account is positive and has a fluctuant dynamics. If in 2005 it was $\$ 6.2 \mathrm{bn}$, then in 2008 the maximum value was reached at $\$ 19.3 \mathrm{bn}$. However, as a consequence of the global financial and economic crisis, at the beginning of 2009, the current account balance is rapidly decreasing - almost twice and equals $\$ 10.2 \mathrm{bn}$. The next recession is observed in 2011-2012,

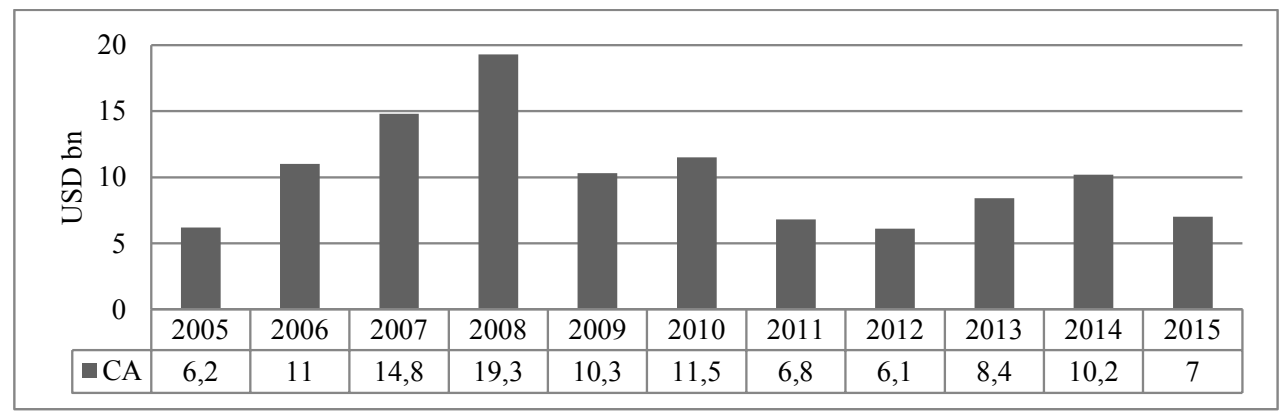

Figure 3. The net current account of Austria

Source: compiled according to data (IMF, 2017) 


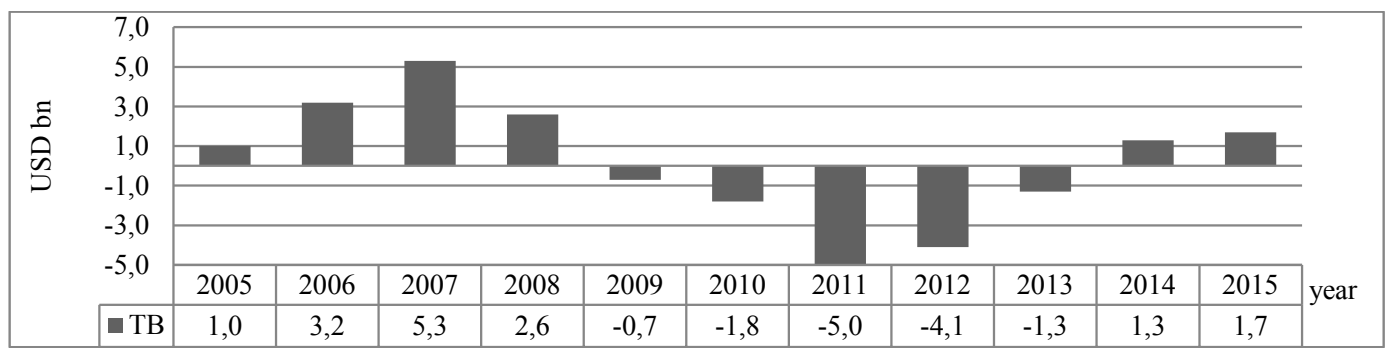

Figure 4. Net trade balance of Austria, USD billion

Source: compiled according to data (IMF, 2017)

which can be explained by the European debt crisis and, as a consequence, the decline in business activity of Austria. However, in general, the balance of current operations of Austria for the whole analysed period has a positive value.

One of the most significant components of Austria's current account is the trade balance (Figure 4). The Austrian economy highly depends on the foreign trade and is closely connected to the economy of other EU countries, especially Germany (33\% of the trade turnover in 2015), Italy (6.2\%), the USA (5.4\%), Switzerland (5.5\%).

The volume of foreign trade in Austria in 2015 reached $\$ 232$ bn, which is $2.6 \%$ more than in the previous year. The main export goods in Austria are chemical products (primarily pharmaceuticals), cars and their components, equipment and paper products. Austria mainly imports machinery and equipment, automobiles, chemicals, metal products, oil and oil products, food products. A slight increase in exports in 2015 is ensured by the countries of Northern and Southern Europe, Asia.

During the whole analysed period, the trade balance has both a negative and a positive value. A close correlation of the trade balance with the current account can be noted. The trade deficit in Austria can be explained by the consequences of the global financial and economic crisis, the debt crisis and uncertainty in the EU.

The balance of primary and secondary income has also a big impact on the Austrian balance of payments (see Figure 5). The primary income account reflects the amount of investment income that must be paid and received for the temporary use of labour, financial resources or non-tangible non-financial assets (income from the use of natural resources by non-residents, etc.). These include: wages, income, taxes on production, income from property (interest, dividends, rent), etc.

The balance of primary income has unstable dynamics, changing several times from a negative value to a positive one. In 2007, the value of primary income was negative $(-\$ 315 \mathrm{~m})$, due to the growth in the number of labour migrants as a result of the EU enlargement, and, as a result, an increase in the Austrian economy's wages to non-resident employees. It is interesting that the high value of the indicator can be seen in 2008 while the balance of primary income increased from $-\$ 315 \mathrm{~m}$ to $\$ 3.4 \mathrm{bn}$. These changes are explained by the dynamics of income from investments, including receipts from financial assets owned by residents of Austria located abroad. From 2011 to 2013, the balance of primary income remains positive, and then in early 2015, it rapidly has a negative value. Such a situation is a result of an Austrian long-term policy aimed at attracting investments. However, due to the negative impact of the European debt crisis, Austria's long-term stability rating was downgraded from AAA to AA+ by the European Financial Stability Facility, which directly influenced Austria's investment attractiveness.

The balance of secondary income, as a balance of current transfers between residents and non-residents of Austria, throughout the whole period from

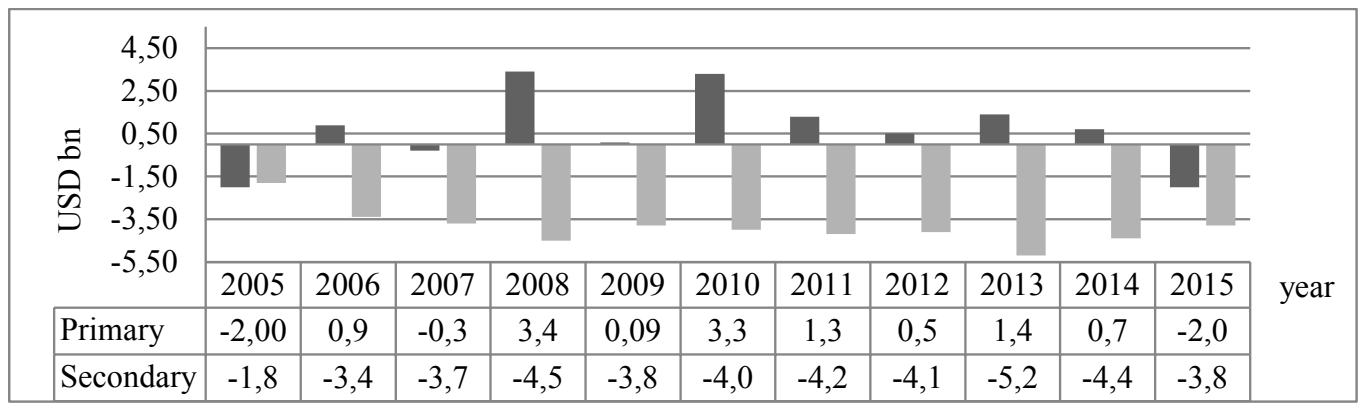

Figure 5. Primary and secondary income of Austria, USD billion

Source: compiled according to data (IMF, 2017) 


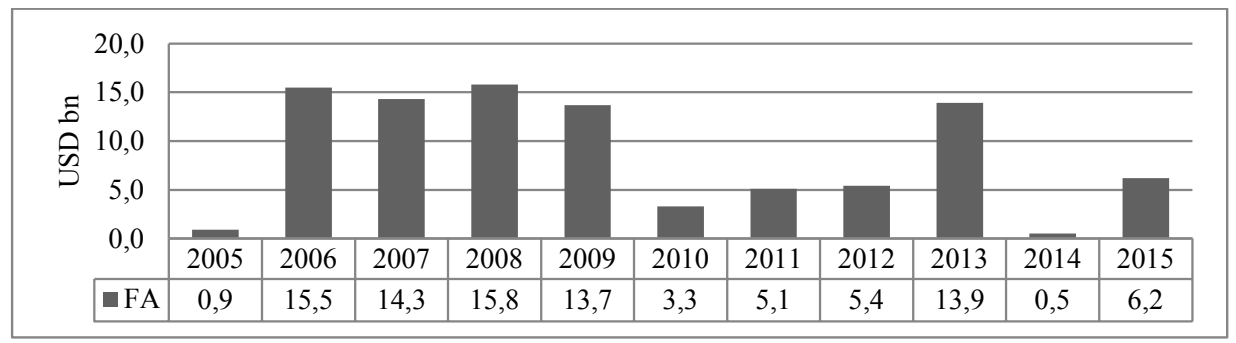

Figure 6. Net financial account of Austria

Source: compiled according to data (IMF, 2017)

2005 to 2015 demonstrates a negative value and varies from $-\$ 1.8$ bn to $-\$ 5.2 \mathrm{bn}$. However, in the last 20132015 , there is an increase in the secondary income indicator, which is a consequence of the reduction in the employment of foreign residents in the country.

The financial account is also a very important component of Austria's balance of payments (Figure 6).

During the period of 2006-2009, the financial account of Austria had a stable position and fluctuated within the limits of $\$ 13.7-\$ 15.5$ bn. In 2010 , this indicator went down by more than 4 times and reached $\$ 3.3 \mathrm{bn}$, after which it gradually grew at $\$ 5.44$ bn in 2012 . In 2013, there was a sharp increase by 2.5 times to $\$ 13.9$ bn.; in 2014 there was a rapid reduction by 28 times. However, in early 2015, this indicator rose again to $\$ 6.2 \mathrm{bn}$.

Austria's international investment position demonstrates the volume of external financial assets and liabilities of the economy at a certain period in time, which is formed as a result of external transactions estimated at current market value (at current market prices and exchange rates), as well as under the influence of other factors. The international investment position of Austria is shown in Figure 7.

Figure 7 presents financial assets belonging to Austrians abroad (assets) and non-residents in Austria (liabilities). From 2005 to 2012, the net international investment position of Austria was negative (liabilities exceeded assets with a difference of $\$ 10 \mathrm{~m}$ to $\$ 60 \mathrm{~m}$ ), which indicates that Austria is a net debtor. From 2005 to
2007, both assets and liabilities increased by almost two: assets from $\$ 651 \mathrm{~m}$ to $\$ 1.136 \mathrm{~m}$, and liabilities from $\$ 714 \mathrm{~m}$ to $\$ 1.176 \mathrm{~m}$. From 2008 and by 2013, the volume of assets, both for Austrians abroad and for non-residents in Austria, remained within \$1-\$1.2 bn. In spite of the global financial and economic crisis and the European debt crisis, Austria's investment activity (both donor and recipient) is stable. From 2013 to 2015, Austria's assets began to exceed liabilities and the balance increased from $\$ 5.8 \mathrm{~m}$ in 2013 up to $\$ 8.9 \mathrm{~m}$ in 2014 and $\$ 10.8 \mathrm{~m}$ in 2015 . At the same time, the total volumes of both assets and liabilities decreased. Assets have decreased from $\$ 1.2$ bn to $\$ 970.7 \mathrm{~m}$, liabilities from $\$ 1.2$ bn to $\$ 960 \mathrm{~m}$. Thus, the net investment position indicates that Austria is a net creditor and confidently reinforces this position.

\section{Influence of the main components of foreign direct investments on Austria's gross domestic product per capita}

In order to determine the impact of the growth of Austria's FDI on the economy as a whole, it is possible to construct a model describing the relationship between the main components of foreign direct investments and the indicator of the country's economic growth - the gross domestic product. The following indicators were selected as independent variables: FDI liabilities, assets of FDI funds, as well as the balance of primary incomes.

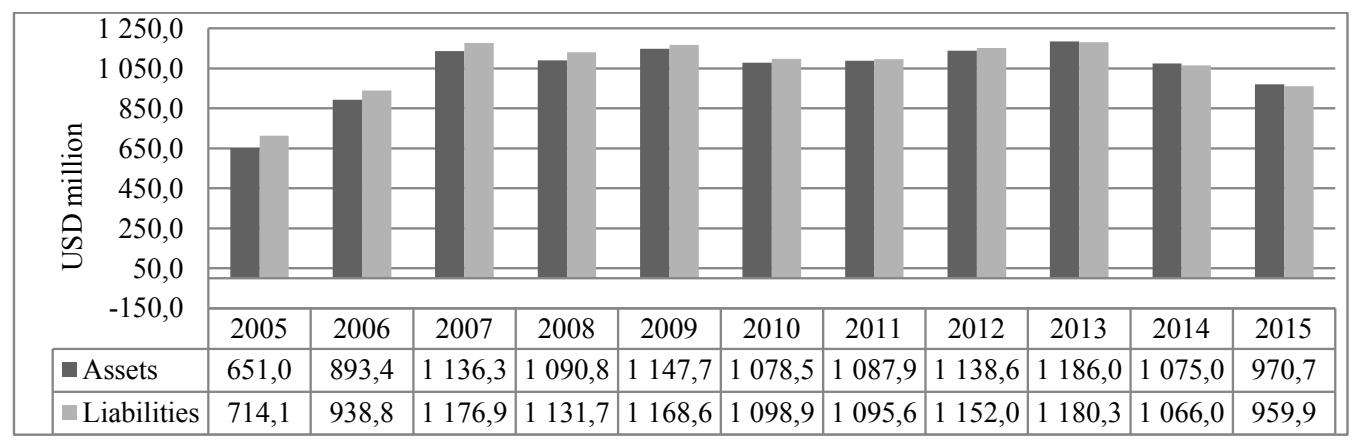

Figure 7. International investment position of Austria

Source: compiled according to data (IMF, 2017) 
The dependent variable is GDP per capita. It should be noted that indicators such as FDI assets and liabilities of FDI funds were not represented in the model because of the high correlation between independent variables, and the relationship between GDP per capita and net foreign assets was insignificant. Thus, the imaginary model has the following form:

$$
G D P=\beta 1^{*} F D I+\beta 22^{*} F D I s o+\beta 3^{*} P I B \text {, }
$$

where GDP - gross domestic product per capita, USD, FDI - FDI liabilities, USD, bn., FDIso - assets of FDI funds, USD, bn., PIB - primary income balance, USD, bn.

The model was estimated on the basis of statistical data for 2000-2017, the indicators were obtained from the UNCTAD statistical database (UNCTAD, 2018).

$$
\begin{aligned}
& G D P=0,372^{*} F D I i+0,755^{*} F D I s o+0,493^{*} P I B \\
& \left(2,335^{* *}\right)\left(4,706^{* * *}\right)\left(3,271^{* * *}\right) \\
& R^{2}=0,823, F=12,405 .
\end{aligned}
$$

This regression model indicates the existence of a significant relationship between the dependent and the variables. The greatest influence on the economy of the country is provided by the assets of foreign direct investment funds, and the connection is direct, i.e. with an increase in this indicator by 1 standard deviation, GDP per capita will increase by 0.755 standard deviations. This dependence is understandable because the economic development of Austria depends very much on the movement of foreign direct investment, namely the country is more a donor, rather than a recipient of FDI. And the existence of direct dependence is explained by the receipt of the benefits of the investing country as a result of reducing costs, obtaining tax benefits and subsidies, and a number of other advantages.

A slightly weaker relationship is observed between the balance of primary incomes and GDP per capita. With the growth of the independent variable by 1 st.d., the GDP per capita grows by 0.493 st.d. There is also a direct dependence. The balance of primary incomes itself has unstable dynamics, changing several times from a negative value to a positive one. And volatility is observed both in terms of income for wages and for investment. In general, the most frequent manifestation is the surplus of the balance of primary incomes, where investment income predominates.

The last indicator - liabilities of FDI - had the least impact on the dependent variable in comparison with the other two. Growth in FDI liabilities leads to an increase in GDP per capita by 0.372 standard deviations. An explanation why in this case the relationship is much weaker in comparison with assets is statistics. For the analysed period, the inward FDI stocks of Austria raised by almost 9 times, while Austria's foreign investments in other countries - almost by 20 times. The second proof of this is the dynamics of Greenfield Investments: the value of foreign investments in the "empty lot" projects in Austria for the whole of the analysed period was four times less than was invested abroad by Austrian investors.

The following reasoning is an explanation of the existence of a direct relationship between variables. As it is known, in theory, the influence of FDI on the recipient country may be ambiguous or even negative. A number of factors that the country must have for a positive effect are connected with this. Among them: the level of education, the internal coefficient of investment, political stability, the terms of trade, the state of the financial sector. Thus, the country under consideration is characterized by administrative transparency, rule of law, business environment, tax legislation, the protection of the inventor's rights, the stability of legislation, political stability.

It should be noted that at the moment the government has taken a course to attract foreign direct investments. For this, supportive programs, regional incentives, incentives for small and medium-sized enterprises, technology incentives and environmental incentives are created. This policy is right for today for the further economic growth of Austria. Proof of this can be an analysis of the dynamics of the balance of payments. So, throughout the considered time the current account of the Austrian economy is in surplus, the financial account is also observed positive. Hence it follows that in order to maintain the surplus and the balance of payments itself, the balance of current operations over the financial balance must prevail. However, in practice, Austria's balance of payments indicator is volatile, in the last 2 years, there has been a deficit caused by the predominance of the financial account. In order to eliminate the deficit, an additional inflow of capital will be required.

So, after carrying out the research it can be found out that the growth of foreign direct investment of Austria as a result of liberalization of the world and European economy as a whole had a positive impact on its GDP. Activities that are aimed at stimulating investment, is fully justified and understandable.

\section{Conclusions}

Foreign direct investment plays an important role in the development of the national economy of Austria. Due to its geopolitical position, Austria for a long period of time had a high investment yield because of the activity in Central, Eastern, and South-Eastern Europe (CESSE). Despite this, Austria has a high level of business activity; the government conducts activities to stimulate investment in $R \& D$ and high-tech enterprises, creating jobs, protecting the environment and etc. The strengths of Austria remain political and macroeconomic stability, a developed financial system, attractive corporate taxation, 
developed infrastructure, highly skilled labour, high productivity and international competitiveness, high quality of life, etc. At this stage, it's important to boost the efficiency of direct investment within the country, their positive impact on the dynamics of the real economy and GDP. The paper proves the increase of stability of Austria's financial system to external shocks. The main factor is a significant improvement in the country's international investment position, which since 2013 has become positive. Thereby, it is possible to forecast a gradual improvement in the balance of the country's primary incomes, which will contribute to the further growth of the current and financial account surplus and will strengthen Austria's influence on the development of the European and global financial systems.

\section{References:}

Austrian Business Agency (2018). Electronic resources. Retrieved from: http://investinaustria.at

Beer, C., Belabed, C.-A., Breitenfellner, A., Ragacs, C., Weber, C. (2017). EU integration and its impact on Austria. Monetary Policy of the Economy. Q1/17. 86-125.

Bellak, Ch. (2010). Inward FDI in Austria and Its Policy Context. Columbia FDI Profile. Retrieved from: http://www.vcc.colum-bia.edu

IMF. (2017). International Financial Statistics. Data by country: Austria. Retrieved from: http://data.imf.org/ regular.aspx?key $=60998113$

U.S. State Department. Bureau of economic and business affairs (2017). Investment Climate Statement 2015 Austria. Retrieved from: http://www.state.gov/e/eb/rls/othr/ics/2015/241467.htm

Kurtovic, S., Dacic, H., Talovic, S. (2016). The Effect of foreign direct investment from Austria on skilled and unskilled labor in Bosnia and Herzegovina. Business and Economic Research, 6(1), 210-223.

Lomachynska, I., Podgorna, I. (2018). Innovation potential: impact on the national economy competitiveness of the EU developed countries. Baltic Journal of Economic Studies, 4(1), 262-270. doi: 10.30525/2256-0742/2018-4$1-262-270$

Onaran, Ozlem (2008). The effects of globalization on wages, employment, and wage share in Austria. Study commissioned by the Chamber of Labour of Vienna. 66 p. Retrieved from: https://media.arbeiterkammer.at/ wien/PDF/studien/The_Effects_of_Globalization_on_Emplayment.pdf

Petrakos, G., Maier, G., Gorselak, C. (2000). Integration and transition in Europe. The economic geography of interaction. London: Routledge.

Simionescu, M. (2016). The relation between economic growth and foreign direct investment during the economic crisis in the European Union. Zbornik radova Ekonomskog fakulteta u Rijeci, 34(1), 187-213.

Sydorova, Z., Yakubovskiy, S. (2017). Development prospects of London as the world's financial center in the conditions of Brexit. Baltic Journal of Economic Studies, 3(4), 238-243. doi: 10.30525/2256-0742/2017-3-4-238-243 UNCTAD (2018). World Investment Report. Country fact sheet: Austria. Retrieved from: https://unctad.org/en/ Pages/DIAE/World\%20Investment\%20Report/Country-Fact-Sheets.aspx

Yakubovskiy, S., Lomachynska, I., Khaddad, K. (2018). Rozvytok bankivskoi systemy Avstrii [Development of Austrian banking system in the conditions of globalization]. Naukovyi visnyk Uzhhorodskoho natsionalnoho universytetu. Seriia: mizhnarodni ekonomichni vidnosyny, 17(2), 148-152. (in Ukrainian) 